\title{
ANALISIS PROFITABILITAS PADA PERUSAHAAN YANG TERGABUNG DALAM INDEKS LQ45 DI BURSA EFEK INDONESIA
}

\author{
Feby Ayu Tri Ananda ${ }^{1}$, Nurjanti Takarini ${ }^{2}$ \\ febyata0705@gmail.com ${ }^{1}$, yayannurjanti@yahoo.com ${ }^{2}$ \\ Universitas Pembangunan Nasional "Veteran" Jawa Timur
}

\begin{abstract}
ABSTRAK
Profitabilitas menjadi suatu tolok ukur untuk melambangkan keberhasilan manajemen suatu perusahaan. Dengan memiliki tingkat profitabilitas yang baik perusahaan dapat terus melaksanakan kegiatan operasionalnya dan meningkatkan nilai perusahaan. Tujuan dilakukannya penelitian ini untuk mengetahui pengaruh modal kerja, likuiditas, dan ukuran perusahaan terhadap profitabilitas. Selain itu penelitian ini untuk mengetahui perbedaan kinerja keuangan perusahaan dari tahun penelitian sebelumnya yang telah diteliti terlebih dahulu, apakah masih sesuai atau telah terjadi perubahan. Objek yang dipakai dalam penelitian ini ialah Perusahaan Manufaktur yang Tergabung dalam Indeks LQ45 di Bursa Efek Indonesia. Sejumlah 10 perusahaan yang diambil berdasarkan teknik sampling jenuh, yaitu dengan mengambil seluruh bagian dari populasi sebagai sampel. Data penelitian yang akan diuji berasal dari data sekunder berupa laporan keuangan tahunan perusahaan yang diterbitkan secara berkala pada BEI. Teknik analisis yang dipakai untuk menguji hipotesis penelitian ialah teknik analisis regresi linier berganda. Hasil analisis regresi berganda memperlihatkan (1) Secara simultan Modal Kerja, Likuiditas, dan ukuran Perusahaan berpengaruh signifikan terhadap Profitabilitas. Sementara secara parsial (2) Modal Kerja berpengaruh negatif signifikan terhadap Profitabilitas (3) Likuiditas dan Ukuran Perusahaan tidak berpengaruh signifikan terhadap Profitabilitas.
\end{abstract}

\section{Kata Kunci : Profitabilitas, Modal Kerja, Likuiditas, Ukuran Perusahaan}

\section{ABSTRACT}

Profitability is a measure by which a company assesses the success of a company's management. Having a good profitability level allows the company to continue its operations and increase its value. Understanding the impact of working capital, liquidity, and firm size is the purpose of this research. In addition, this research aims to know the differences in company's financial performance from a previous reserach, wehether it still corresponded or had undergone changes. The object of this research is the manufacturing company that makes up the LQ45 stock index in the Indonesian Stock Exchange. A total of 10 companies was taken to according to saturated sampling techniques, which is taking all the parts of the population as samples. The research data to be tested comes from secondary data according to the company's annual report published periodically in BEI. Analysis techniques used in testing research hypotheses are multiple linier regressin. The results shows the regression analysis that (1) working capital, liquidity, and firm size simultaneously have a significant effect on profitability. (2) working capital has a significant effect on profitability. (3) liquidity and firm size have no significant effect on profitability.

Keywords : Profitability, Working Capital, Liquidity, Firm Size 


\section{PENDAHULUAN}

Perusahaan adalah salah satu bagian penting dari kegiatan perekonomian yang ada di Indonesia. Selain sebagai sarana untuk pemenuhan kebutuhan masyarakat, perusahaan juga mengontrol laju pertumbuhan ekonomi Indonesia.Perusahaan merupakan suatu organisasi yang umumnya mempunyai tujuan yang ingin dicapai, yaitu untuk memakmurkan pemegang sahamnya. Menurut Prihadi (2013:8) ada dua hal yang dapat memberikan kesejahteraan bagi pemegang saham, yaitu deviden dan capital gain. Besarnya ukuran deviden yang akan diperoleh bagi setiap pemegang saham dipengaruhi oleh seberapa besar kemampuan perusahaan dalam menghasilkan profitabilitas. Sehingga dapat dikatakan juga bahwa tujuan suatu perusahaan ialah untuk memperoleh laba.

Profitabilitas menunjukkan keterampilan perusahaan dalam memperoleh laba berdasarkan pada sumber daya yang dimilikinya. Besarnya profitabilitas yang didapat oleh perusahaan menjadi ukuran keberhasilan manajemen suatu perusahaan. Profitabilitas yang tinggi memperlihatkan bahwa perusahaan memiliki kinerja yang efektif juga efisien, dan memiliki prospek dimasa depan. Hal ini akan menjadi sinyal positif bagi investor sehingga investor juga akan memberikan respon positif denganberinvestasi (Kusumawati \& Rosady, 2018). Namun untuk mencapai tujuan - tujuan tersebut diperlukan adanya perencanaan serta kontrol dari pihak manajemen perusahaan, seperti menentukan kebijakan pendanaan.

Tabel 1 Return On Asset (ROA) Perusahaan Manufaktur yang Tergabung dalam Indeks LQ45 di Bursa Efek Indonesia

\begin{tabular}{|c|c|c|c|c|c|c|}
\hline \multirow{2}{*}{ No. } & \multirow{2}{*}{ Code } & \multirow{2}{*}{ Perusahaan } & \multicolumn{4}{|c|}{ Return On Asset } \\
\hline & & & 2016 & 2017 & 2018 & 2019 \\
\hline 1 & ASII & Astra Internasional Tbk. & 6,99 & 7,84 & 7,94 & 7,56 \\
\hline 2 & GGRM & Gudang Garam Tbk. & 10,60 & 11,62 & 11,28 & 13,83 \\
\hline 3 & HMSP & HM Sampoerna tbk. & 30,02 & 29,37 & 29,05 & 26,96 \\
\hline 4 & ICBP & Indofood CBP Sukses Makmur Tbk. & 12,56 & 11,21 & 13,56 & 13,85 \\
\hline 5 & INDF & Indofood Sukses Makmur Tbk. & 6,41 & 5,85 & 5,14 & 6,14 \\
\hline 6 & INTP & Indocement Tunggal Prakarsa Tbk. & 12,84 & 6,44 & 4,12 & 6,62 \\
\hline 7 & KLBF & Kalbe Farma Tbk. & 15,44 & 14,76 & 13,76 & 12,52 \\
\hline 8 & SMGR & Semen Indonesia (Persero) Tbk. & 10,25 & 4,17 & 6,08 & 2,97 \\
\hline 9 & SRIL & Sri Rejeki Isman Tbk. & 6,27 & 5,70 & 6,20 & 5,62 \\
\hline 10 & UNVR & Unilever Indonesia Tbk. & 38,16 & 37,05 & 44,68 & 35,80 \\
\hline & & Total & 149,55 & 134,01 & 141,80 & 131,88 \\
\hline & & Rata - rata & 14,95 & 13,40 & 14,18 & 13,19 \\
\hline & & Pertumbuhan & & $-10,39$ & 5,81 & $-7,00$ \\
\hline
\end{tabular}

Sumber : $\underline{w w w . i d x . c o . i d ~(d a t a ~ d i o l a h) ~}$

Salah satu sektor yang memiliki pengaruh besar ialah industri manufaktur. Perusahaan manufaktur ialah perusahaan yang mempunyai proses produksi, dimana perusahaan akan membeli bahan mentah dan mengolahnya menjadi produk jadi atau setengah jadi dengan menggunakan alat produksi seperti mesin.Sementara perusahaan yang ada dalam Indeks LQ45 ialah perusahaan yang mempunyai tingkat likuiditas yang tinggi dan kapitalisasi pasar yang besar. Perusahaan manufaktur yang tergabung dalam 
Indeks LQ45 merupakan perusahaan besar yang mayoritas produknya banyak digunakan oleh masyarakat Indonesia. Sehingga sahamnya banyak diperdagangkan karena dianggap memiliki prospek yang baik dan mencerminkan bahwa perusahaan memiliki kapitalisasi pasar yang besar. Namun berdasarkan pada tabel 1 mengindikasi bahwa nilai profitabilitasperusahaan manufaktur yang tergabung dalam Indeks LQ45 periode 2016 2019 cenderung mengalami penurunan. Penurunan profitabilitas menandakan adanya masalah pada kinerja keuangan perusahaan yang diakibatkan oleh berbagai faktor.

Faktor tersebut bisa berasal dari internal perusahaan maupun eksternal perusahaan. Faktor eksternal yang dapat mempengaruhi kinerja perusahaan adalah kondisi ekonomi yang ada di Indonesia. Dilansir dari liputan 6.com (10/10) badan pusat statistik mencatat selama september 2020 terjadi deflasi sebesar 0,05\%. Deflasi terjadi berturut - turut semenjak kuartal III. Hal ini disebabkan karena pandemi Covid-19 yang sedang terjadi. Sehingga daya beli masyarakat cenderung mengalami penurunan yang mengakibatkan penjualan perusahaan ikut menurun, hal ini tentu akan berpengaruh terhadap profitabilitas yang dihasilkan. Sementara faktor - faktor internal dalam perusahaan tak lepas dari elemen yang digunakan untuk menjalankan kegiatan operasionalnya.

Menurut Wibowo dan Wartini (2011) berdasarkan hasil penelitiannya pada perusahaan manufaktur diketahui perputaran modal kerja berpengaruh positif signifikan terhadap profitabilitas, yang artinya besar kecilnya profitabilitas yang dihasilkan dipengaruhi oleh efisiensi modal kerja. Sementara berbeda dengan hasil penelitian Meidiyustiani (2016) yang menyatakan perputaran modal kerja tidak berpengaruh signifikan terhadap profitabilitas.Perputaran yang rendah dan kurang efektif menyebabkan penjualan berkurang sehingga profitabilitas tidak mengalami kenaikan.

Sementara Ambariwati et al (2015) menyatakan dalam penelitiannya bahwa Likuiditas tidak berpengaruh signifikan terhadap profitabilitas. Current Rasio yang tinggi menandakan kinerja yang kurang bagus, karena memperlihatkan banyak aktiva yang tidak dimanfaatkan dengan baik sehingga dapat menurunkan profitabilitas. Berbanding terbalik dengan penelitian Felany dan Worokinasih (2018) Likuiditas berpengaruh positif signfikan terhadap profitabilitas. Likuiditas menginterpretasikan perusahaan mempunyai banyak sumber aset yang dapat dijadikan kas guna melunasi kewajiban lancarnya dan profitabilitas meningkat.

Pada penelitian Barus dan Leliani (2013) Ukuran Perusahaan berpengaruh positif signifikan terhadap Profitabilitas. Ia mengatakan perusahaan manufaktur memiliki sumber daya yang besar sehingga dapat menginvestasikan sebagian asetnya kedalam aktiva guna untuk memenuhi permintaan produknya dan memperluas pangsa pasar. Sehingga semakin besar aktiva maka ukuran perusahaan juga semakin besar dan semakin tinggi profitabilitas yang dihasilkan. Namun hal tersebut tidak sejalan dengan penelitian Assani (2019) perusahaan yang besar belum tentu dapat menghasilkan profitabilitas lebih baik dari pada perusahaan start up atau kecil. Hal ini dikarenakan perusahaan besar yang asetnya melimpah belumtentu dapat menggunakan dengan maksimal untuk memperoleh keuntungan. 


\section{Rumusan Masalah}

Berdasarkan penjelasan latar belakang diatas penulis dapat merumuskan permasalahan dalam penelitian ini yaitu, Apakah Modal Kerja, Likuiditas dan Ukuran Perusahaan berpengaruh positif signifikan terhadap Profitabilitas?

\section{Tujuan Penelitian}

Dan berdasarkan rumusan masalah tersebut tujuan dari penelitian ini ialah untuk menganalisis dan mengetahui pengaruh Modal Kerja, Likuiditas dan Ukuran Perusahaan terhadap Profitabilitas pada Perusahaan Manufaktur yang Tergabung dalam Indeks LQ45 di Bursa Efek indonesia.

\section{LANDASAN TEORI DAN PENGEMBANGAN HIPOTESIS Profitabilitas}

Profitabilitas ialah rasio yang dipakai mengukur kemampuan perusahaan dalam memperoleh keuntungan. Tingkat efektivitas manajemen suatu perusahaan dapat ternilai melalui rasio profitabilitas, hal ini terlihat dari tingkat keuntungan yang diperoleh dari suatu penjualan dan pendapatan investasi (Kasmir, 2019:198). Pada penelitian ini indikator yang diproksikan untuk menilai tingkat profitabilitas ialahReturn On Asset (ROA). Dengan menggunakan ROA memperlihatkan bahwa profitabilitas perusahaan diukur berdasarkan tingkat aset tertentu, nilai rasio yang besar memperlihatkan keefektivitasan pengelolaan aset yang baik. Menurut (Hanafi, 2016:42) rumus untuk mencari Return On Aset (ROA) sebagai berikut :

$$
\text { Return On Asset (ROA) }=\frac{\text { Laba Bersih }}{\text { Total Aset }} \times 100 \%
$$

\section{Modal kerja}

Modal kerja merupakan kelebihan dari aktiva lancar atas utang lancarnya. Kelebihan ini dianggap sebagai modal kerja bersih dalam perusahaan yang bersumber dari utang jangka panjang dan modal sendiri (Jumingan, 2014:66). Fungsi dari modal kerja sendiri dipergunakan untuk membiayai kegiatan operasional perusahaan dalam setiap harinya, dimana dana yang keluar dari perusahaan diharap agar segera kembali masuk dalam waktu yang singkat melalui hasil penjualan produksinya (Riyanto, 2010:57). Pada penelitian ini indikator yang diproksikan untuk menilai tingkat efisiensi penggunaan modal kerja adalah Perputaran Modal Kerja. Perputaran modal kerja memperlihatkan jumlah rupiah penjualan netto yang didapat dari setiap rupiah modal kerja (Jumingan, 2014:132). Adapun rumus untuk mencari Perputaran Modal Kerja sebagai berikut :

$$
\text { Perputaran Modal Kerja }=\frac{\text { Penjualan }}{\text { Modal Kerja Bersih }}
$$

Semakin singkat waktu yang digunakan untuk modal kerja berputar, menandakan semakin cepat perputarannya. Dengan begitu penjualan yang diperoleh akan semakin besar dan keuntungan perusahaan akan meningkat.Sesuai penelitian Ambarwati et al (2015) yang 
mengatakan secara parsial perputaran modal kerja berpengaruh signifikan positif terhadap profitabilitas. Sementara berbanding terbalik dengan hasil penelitian Meidiyustiani (2016) yang menyatakan bahwa perputaran modal kerja tidak berpengaruh terhadap profitabilitas. Fluktuasi yang terjadi dalam penjualan yang diakibatkan oleh faktor musim dan siklus akan mempengaruhi kebutuhan modal kerja. Perputaran modal kerja yang tidak cepat menyebabkan penjualan menurun sehingga profitabilitas juga ikut menurun.

\section{$\mathrm{H}_{1}$ : Modal Kerja berpengaruh positif terhadap Profitabilitas}

\section{Likuiditas}

Konsep likuiditas menerangkan tentang ketermpilan perusahaan untuk membayar utang jangka pendek yang tidak lebih dari satu tahun. Likuiditas memperlihatkan kinerja manajemen yang ditinjau dari seberapa jauh manajemen mampu untuk mengolah modal kerja yang didanai kas dan utng lancar perusahaan (Harmono, 2018:106). Menurut Kasmir (2019:135) likuiditas yang diproksikan dengan menggunakan Current Rasio memiliki standar yang dianggap cukup baik bagi suatu perusahaan yaitu 200\% (2:1). Menurut Hanafi (2016:37) rumus current rasio sebagai berikut :

$$
\text { Current Rasio }=\frac{\text { Aktiva Lancar }}{\text { Utang Lancar }} \times 100 \%
$$

Sartono (2004) dalam Alifianda dan Takarini (2020) likuiditas memperlihatkan perusahaan mempunyai kemampuan untuk membayar utang lancarnya tepat pada waktunya, dengan begitu makin tinggi nilai current rasio menunjukkan kemampuan perusahaan untuk membayar hutang lancarnya semakin besar. Hal ini mengisyaratkan semakin likuid aktiva lancar maka akan semakin tinggi nilai profitabilitas yang diperoleh, dapat dinyatakan dalam penelitiannya bahwa likuiditas berpengaruh positif signifikan terhadap profitabilitas.Sementara penelitian Barus dan Leliani (2013) memiliki hasil yang berbeda,current rasio tidak berpengaruh terhadap profitabilitas perusahaan. Sebab tingginya likuiditas perusahaan akan membuat aktiva lancar berlebih dan menjadi tidak produktif sehingga akan menurunkan profitabilitas perusahaan (Van Horne, 2012 dalam Yuliati 2013).

\section{$\mathrm{H}_{2}$ : Likuiditas berpengaruh positif terhadap Profitabilitas}

\section{Ukuran Perusahaan}

Ukuran perusahaan ialah suatu penetapan besar kecilnya perusahaan. Ukuran perusahaan dapat diukur dengan menggunakan total aset yang dipunya oleh perusahaan. Semakin tinggi total aset menunjukkan harta yang dipunya oleh perusahaan semakin besar pula. Menurut teori critial resources dalam penelitian Ratnasari (2016) rumus ukuran perusahaan sebagai berikut :

$$
\text { Firm Size }=L N(\text { Total Aset })
$$

Semakin besar suatu perusahaan akan memberikan kesempatan untuk dapat menggunakan modalnya dengan lebih efisien dan memiliki kemungkinan lebih besar untuk dapat bekerja dengan biaya produksi lebih rendah. Sehingga harga perunitnya juga akan lebih rendah, hal ini memperkuat posisinya dalam pasar produk yang dihasilkan dimana dapat memberikan keuntungan. Searah dengan penelitian Ulfa \& Wahyu (2020) yang mengatakan ukuran 
perusahaan berpengaruh positif signifikan terhadap profitabilitas. Namun berbeda dengan hasil penelitian Rasyid et al (2014) yang mengatakan ukuran perusahaan tidak berpengaruh signifikan terhadap profitbilitas. Karena semakin besar ukuran perusahaan akan terjadi kesenjangan antara tujuan perusahaan dan tujuan pribadi yang mengakibatkan maksimalisasi keuntungan akan tergantikan oleh fungsi maksimalisasi manajerial.

\section{$\mathrm{H}_{3}$ : Ukuran Perusahaan berpengaruh positif terhadap Profitabilitas}

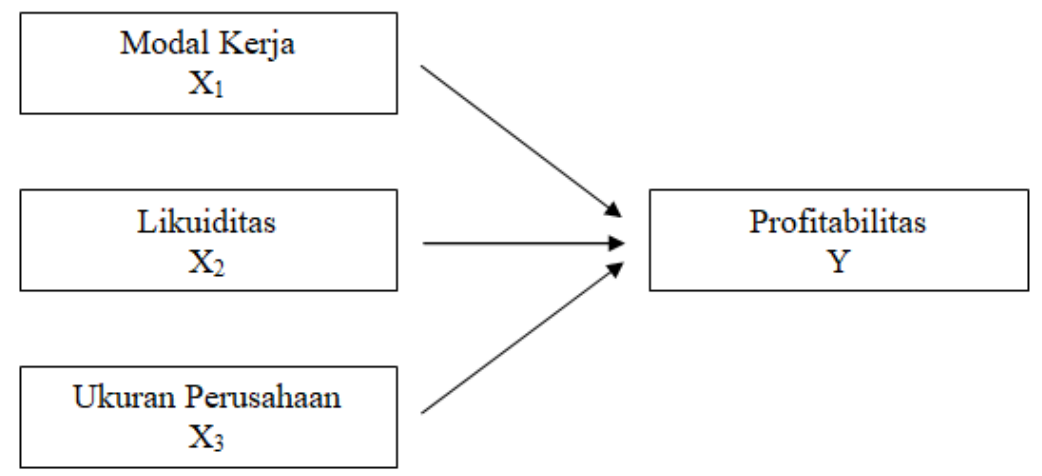

\section{Gambar 1. Kerangka Konseptual}

\section{METODE PENELITIAN}

Metode yang digunakan dalam penelitian ini ialah Metode Kuantitatif Asosiatif, yaitu penelitian kausalitas dimana penelitian yang hubungan antar variabelnya dalam bentuk sebab akibat. Populasi pada penelitian ini meliputi Perusahaan Manufaktur yang Tergabung dalam Indeks LQ45 di Bursa Efek Indonesia. Teknik sampling jenuh dipakai sebagai teknik pengambilan sampel untuk penelitian ini, dengan mengambil seluruh anggota populasi sebagai sampel. Maka sampel yang diperoleh sebagai objek penelitian ialah 10 Perusahaan Manufaktur yang Tergabung dalam Indeks LQ45 yang dapat dilihat pada tabel 1. Jenis data yang gunakan adalah data sekunder, berupa laporan keuangan tahunan perusahaan periode 2016 hingga 2019 yang diterbitkan secara berkala dan dapat diakses melalui website resmi Bursa Efek Indonesia. Data dihimpun dengan menggunakan teknik Dokumentasi. Teknik analisis yang dipakai untuk menguji hipotesis penelitian ialah Analisis regresi linier berganda. Selain itu dilakukan pula uji asumsi klasik guna memastikan bahwa data terdistribusi normal dan memenuhi asumsi klasik. Diantaranya Uji Outlier dan Uji Normalitas, Uji Multikolonieritas, Uji Autokolerasi dan Uji Heteroskedastisitas. Statistical Product and Service Solution (SPSS) adalah aplikasi yang dipakai untuk mengolah data penelitian. 


\section{HASIL ANALISIS DAN PEMBAHASAN}

Uji Outlier

Tabel 2. Hasil Uji Outlier

Residuals Statistics ${ }^{\mathrm{a}}$

\begin{tabular}{|l|r|r|r|r|r|}
\hline & Minimum & Maximum & Mean & Std. Deviation & \multicolumn{1}{l|}{ N } \\
\hline Predicted Value & -13.6998 & 31.2494 & 13.9307 & 6.89104 & 40 \\
Std. Predicted Value & -4.010 & 2.513 & .000 & 1.000 & 40 \\
Standard Error of & 1.477 & 6.090 & 2.588 & 1.053 & 40 \\
Predicted Value & & & & & \\
Adjusted Predicted Value & -30.8560 & 27.3241 & 13.1742 & 8.57213 & 40 \\
Residual & -12.11831 & 18.83983 & .00000 & 8.47511 & 40 \\
Std. Residual & -1.374 & 2.136 & .000 & .961 & 40 \\
Stud. Residual & -1.405 & 2.952 & .038 & 1.063 & 40 \\
Deleted Residual & -12.67260 & 35.99599 & .75655 & 10.61670 & 40 \\
Stud. Deleted Residual & -1.425 & 3.344 & .056 & 1.106 & 40 \\
Mahal. Distance & .118 & 17.613 & 2.925 & 3.364 & 40 \\
Cook's Distance & .000 & 1.984 & .079 & .314 & 40 \\
Centered Leverage Value & .003 & .452 & .075 & .086 & 40 \\
\hline
\end{tabular}

a. Dependent Variable: $\mathrm{Y}=\mathrm{ROA}$

Diperoleh hasilanalisis uji outlier data ini menunjukkan nilai Distance Maximum sebesar 17,613 < 18,467 yang artinya tidak terdapat nilai Mahal. Hal ini mengartikan bahwa tidak terdapat outlier pada data sehingga data memiliki kualitas yang baik untuk diolah lebih lanjut.

\section{Uji Normalitas}

Diperoleh hasil analisis dengan uji ini, terdapat dua data yang tidak terdistribusi normal yaitu Perputaran Modal Kerja (X1) dengan hasil sebesar 0,013 dan Ukuran Perusahaan (X3) sebesar 0,000 karena memiliki signifikansi lebih kecil dari 0,05. Sedangkan hanya Likuiditas (X3) dengan hasil 0,153 yang memiliki distribusi normal. Namun pada uji kualitas data memperlihatkan hasil bahwa tidak terdapat outlier, maka data penelitian ini mempunyai kualitas yang baik sehingga dapat diolah lebih lanjut. 
Tabel 3. Uji Normalitas

One-Sample Kolmogorov-Smirnov Test

\begin{tabular}{|ll|r|r|r|}
\hline & & $\begin{array}{c}\text { X1 } \\
\text { Perputaran } \\
\text { Modal } \\
\text { Kerja }\end{array}$ & X2 = CR & X3 = Size \\
\hline $\mathrm{N}$ & Mean & 40 & 40 & 40 \\
Normal Parameters ${ }^{\mathrm{a}, \mathrm{b}}$ & Std. Deviation & .72566 & .63094 & .22021 \\
& Absolute & .166 & .120 & .270 \\
Most Extreme Differences & Positive & .166 & .076 & .270 \\
& Negative & -.070 & -.120 & -.206 \\
& & .166 & .120 & .270 \\
Test Statistic & & $.013^{\mathrm{c}}$ & $.153^{\mathrm{c}}$ & $.000^{\mathrm{c}}$ \\
Asymp. Sig. (2-tailed) & & &
\end{tabular}

a. Test distribution is Normal.

b. Calculated from data.

c. Lilliefors Significance Correction.

\section{Uji Multikolinieritas}

Tabel 4. Uji Multikolinieritas

Coefficients $^{\mathrm{a}}$

\begin{tabular}{|c|c|c|c|c|c|c|c|c|c|}
\hline \multirow{2}{*}{\multicolumn{2}{|c|}{ Model }} & \multicolumn{2}{|c|}{$\begin{array}{c}\text { Unstandardized } \\
\text { Coefficients }\end{array}$} & \multirow{2}{*}{$\begin{array}{c}\text { Standardized } \\
\text { Coefficients } \\
\text { Beta }\end{array}$} & \multirow[b]{2}{*}{$\mathrm{t}$} & \multirow[b]{2}{*}{ Sig. } & \multirow{2}{*}{$\begin{array}{c}\text { Correlations } \\
\text { Partial }\end{array}$} & \multicolumn{2}{|c|}{$\begin{array}{l}\text { Collinearity } \\
\text { Statistics }\end{array}$} \\
\hline & & B & $\begin{array}{l}\text { Std. } \\
\text { Error }\end{array}$ & & & & & Tolerance & VIF \\
\hline \multirow[t]{5}{*}{1} & (Constant) & 23.030 & 6.118 & & 3.765 & .001 & & & \\
\hline & $\mathrm{X} 1=$ & & & & & & & & \\
\hline & $\begin{array}{l}\text { Perputaran } \\
\text { Modal Kerja }\end{array}$ & -.901 & .186 & -.628 & -4.832 & .000 & -.627 & .990 & 1.010 \\
\hline & $\mathrm{X} 2=\mathrm{CR}$ & -.003 & .011 & -.044 & -.301 & .765 & -.050 & .765 & 1.307 \\
\hline & $\mathrm{X} 3=$ Size & -.239 & .350 & -.101 & -.683 & .499 & -.113 & .770 & 1.299 \\
\hline
\end{tabular}

a. Dependent Variable: $\mathrm{Y}=\mathrm{ROA}$

Diperoleh hasil uji analisis asumsi klasik multikolinieritas terhadap regresi linier berganda tidak menunjukkan adanya gejala multikolinieritas. Karena nilai VIF dari ke tiga variabel lebih kecil dari 10 .

\section{Uji Heteroskedastisitas}

Diperoleh hasil uji analisis asumsi klasik heteroskedastisitas melihatkan semua variabel tidak punya kolerasi yang signifikan antara residual dengan variabel bebasnya, sehingga disimpulkan Tidak terjadi Heteroskedastisitas. Dimana nilai signifikansi masing - masing variabel lebih kecil dari 0,05 dengan rincian sebagai berikut: Perputaran Modal Kerja (X1) mempunyai hasil sebesar 0,799, Likuiditas (X2) sebesar 0,434 dan Ukuran Perusahaan (X3) sebesar 0,68. 
Tabel 5. Uji Heteroskedastisitas

Correlations

\begin{tabular}{|c|c|c|c|c|c|c|}
\hline & & & $\begin{array}{c}\text { Unstandardized } \\
\text { Residual }\end{array}$ & $\begin{array}{c}\mathrm{X} 1= \\
\text { Perputaran } \\
\text { Modal } \\
\text { Kerja } \\
\end{array}$ & $\mathrm{X} 2=\mathrm{CR}$ & $\begin{array}{c}\mathrm{X} 3= \\
\text { Size }\end{array}$ \\
\hline \multirow{12}{*}{$\begin{array}{l}\text { Spearman's } \\
\text { rho }\end{array}$} & \multirow{3}{*}{$\begin{array}{l}\text { Unstandardized } \\
\text { Residual }\end{array}$} & Correlation Coefficient & 1.000 & .042 & -.127 & -.066 \\
\hline & & Sig. (2-tailed) & & .799 & .434 & .686 \\
\hline & & $\mathrm{N}$ & 40 & 40 & 40 & 40 \\
\hline & \multirow{3}{*}{$\begin{array}{l}\text { X1 = } \\
\text { Perputaran } \\
\text { Modal Kerja }\end{array}$} & Correlation Coefficient & .042 & 1.000 & $-.365^{\circ}$ & .074 \\
\hline & & Sig. (2-tailed) & .799 & & .020 & .649 \\
\hline & & $\mathrm{N}$ & 40 & 40 & 40 & 40 \\
\hline & \multirow[t]{3}{*}{$\mathrm{X} 2=\mathrm{CR}$} & Correlation Coefficient & -.127 & $-.365^{*}$ & 1.000 & $.424^{4}$ \\
\hline & & Sig. (2-tailed) & .434 & .020 & & .006 \\
\hline & & $\mathrm{N}$ & 40 & 40 & 40 & 40 \\
\hline & \multirow[t]{3}{*}{$\mathrm{X} 3=$ Size } & Correlation Coefficient & -.066 & .074 & $.424^{* 4}$ & 1.000 \\
\hline & & Sig. (2-tailed) & .686 & .649 & .006 & \\
\hline & & $\mathrm{N}$ & 40 & 40 & 40 & 40 \\
\hline
\end{tabular}

*. Correlation is significant at the 0.05 level (2-tailed).

**. Correlation is significant at the 0.01 level (2-tailed).

\section{Uji Autokolerasi}

Tabel 6. Uji Autokolerasi

Model Summary ${ }^{b}$

\begin{tabular}{|c|c|c|c|c|c|c|c|}
\hline \multirow[b]{2}{*}{ Model } & \multirow[b]{2}{*}{$\mathrm{R}$} & \multirow[b]{2}{*}{$\begin{array}{c}\mathrm{R} \\
\text { Square }\end{array}$} & \multirow[b]{2}{*}{$\begin{array}{l}\text { Adjusted } \\
\text { R Square }\end{array}$} & \multirow{2}{*}{$\begin{array}{l}\text { Std. Error } \\
\text { of the } \\
\text { Estimate }\end{array}$} & \multicolumn{2}{|c|}{ Change Statistics } & \multirow[b]{2}{*}{$\begin{array}{l}\text { Durbin- } \\
\text { Watson }\end{array}$} \\
\hline & & & & & $\begin{array}{c}\text { R Square } \\
\text { Change }\end{array}$ & $\begin{array}{l}\text { Sig. F } \\
\text { Change }\end{array}$ & \\
\hline 1 & $.631^{\mathrm{a}}$ & .398 & .348 & 8.82117 & .398 & .000 & 2.457 \\
\hline
\end{tabular}

a. Predictors: (Constant), X3 = Size, X1 = Perputaran Modal Kerja, X2 = CR

b. Dependent Variable: $\mathrm{Y}=\mathrm{ROA}$

Diperoleh hasil uji asumsi klasik autokolerasi memperlihatkan nilai Durbin Watson sebesar 2,457, angka ini terletak di daerah yang tidak ada autokolerasi baik positif maupun negatif. Sehingga disimpulkan Tidak ada gelaja Autokolerasi.Terlihat pada gambar statistik dibawah ini. $\mathrm{k}=3, \mathrm{n}=40$

$\mathrm{dL}=1,3384, \mathrm{dU}=1,6589$

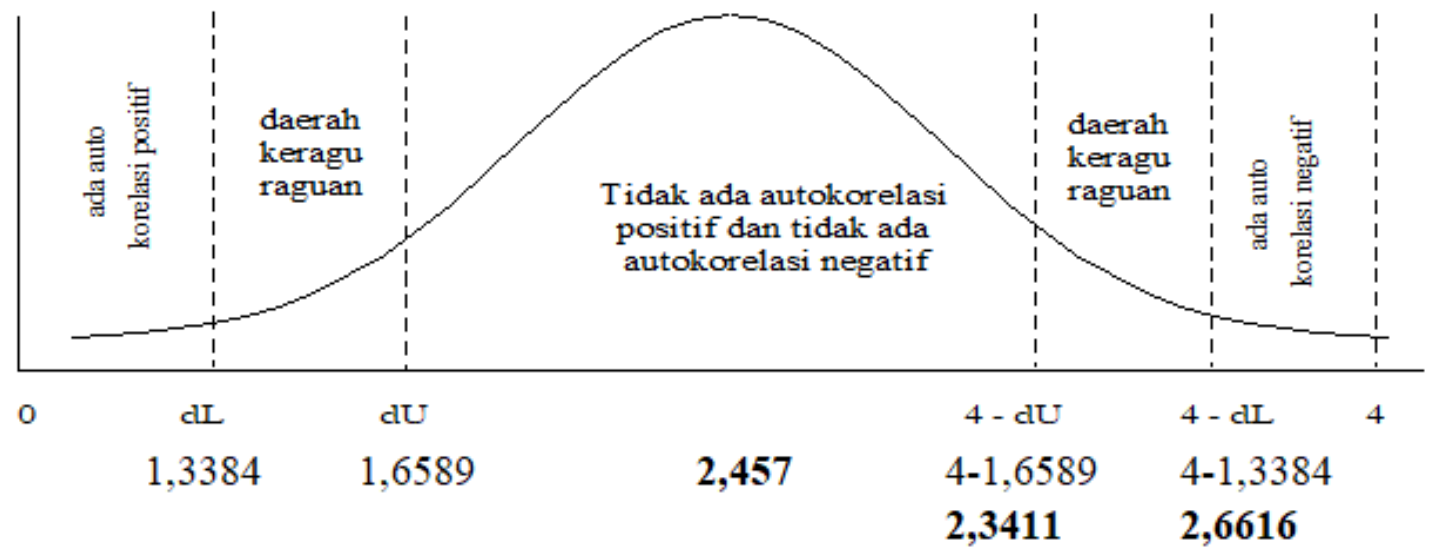




\section{Analisis Regresi Linier Berganda}

Bertujuan untuk mengetahui hubungan kausalitas dan besarnya pengaruh antara variabel Perputaran Modal Kerja, Likuiditas dan Ukuran Perusahaan terhadap Profitabilitas pada Perusahaan Manufaktur yang Tergabung dalam Indeks LQ45 periode 2016 - 2019. Dengan hasil analisis sebagai berikut :

\section{Tabel 7. Hasil Regresi Linier Berganda}

\begin{tabular}{|c|c|c|c|c|c|c|c|c|c|}
\hline \multicolumn{10}{|c|}{ Coefficients $^{\text {a }}$} \\
\hline \multirow{2}{*}{\multicolumn{2}{|c|}{ Model }} & \multicolumn{2}{|c|}{$\begin{array}{c}\text { Unstandardized } \\
\text { Coefficients }\end{array}$} & \multirow{2}{*}{$\begin{array}{c}\text { Standardized } \\
\text { Coefficients } \\
\text { Beta }\end{array}$} & \multirow[b]{2}{*}{$\mathrm{t}$} & \multirow[b]{2}{*}{ Sig. } & \multirow{2}{*}{$\begin{array}{c}\text { Correlations } \\
\text { Partial }\end{array}$} & \multicolumn{2}{|c|}{$\begin{array}{l}\text { Collinearity } \\
\text { Statistics }\end{array}$} \\
\hline & & $\mathrm{B}$ & Error & & & & & Tolerance & VIF \\
\hline \multirow[t]{6}{*}{1} & (Constant) & 23.030 & 6.118 & & 3.765 & .001 & & & \\
\hline & $\mathrm{x} 1=$ & & & & & & & & \\
\hline & Perputaran & -.901 & .186 & -.628 & -4.832 & .000 & -.627 & .990 & 1.010 \\
\hline & Modal Kerja & & & & & & & & \\
\hline & $\mathrm{X} 2=\mathrm{CR}$ & -.003 & .011 & -.044 & -.301 & .765 & -.050 & .765 & 1.307 \\
\hline & $\mathrm{X} 3=$ Size & -.239 & .350 & -.101 & -.683 & .499 & -.113 & .770 & 1.299 \\
\hline
\end{tabular}

a. Dependent Variable: $\mathrm{Y}=\mathrm{ROA}$

$$
\text { ROA }(Y)=23,030-0,901 \text { PMK - 0,003 CR - 0,239 UP + } \mu \mathrm{i}
$$

Dengan hasil analisis persamaan regresi berganda diatas, dapat diuraikan sebagai berikut :

1. Nilai konstanta sebesar 23,030 menunjukan apabila variabel Perputaran Modal Kerja (X1), Likuiditas diukur dengan Current Rasio (X2), dan Ukuran Perusahaan (X3) besarnya konstan atau nol. Maka besarnya ROA akan naik sebesar 23,030.

2. Nilai koefisien regresi pada variabel Perputaran Modal Kerja (X1) sebesar -0,901 menunjukan perubahan yang berlawanan arah antara Perputaran Modal Kerja dengan Return On Asset. Yang mengartikan bila Perputaran Modal Kerja (X1) naik satu satuan maka ROA akan turun sebesar 0,901. Demikian sebaliknya bila Perputaran Modal Kerja (X1) turun 1 satuan maka ROA akan naik sebesar 0,901 dengan asumsi variabel Likuiditas yang diukur dengan Current Rasio (X2) dan Ukuran Perusahaan (X3) adalah konstan.

3. Nilai koefisien regresi variabel Likuiditas yang diukur dengan Current Rasio (X2) sebesar -0,003 memperlihatkan perubahan yang berlawanan arah antara Likuiditas yang diukur dengan Current Rasio dengan Return On Asset. Yang mengartikan bila Current Rasio (X2) naik satu satuan maka ROA akan turun sebesar 0,003. Demikian sebaliknya bila Current Rasio (X2) turun satu satuan maka ROA akan naik sebesar 0,003 dengan asumsi variabel Perputaran Modal Kerja (X1) dan Ukuran Perusahaan (X3) adalah konstan.

4. Nilai koefisien regresi variabel Ukuran Perusahaan (X3) sebesar -0,239 memperlihatkan perubahan yang berlawanan arah antara Ukuran Perusahaan dengan Return On Asset. Yang mengartikan bila Ukuran Perusahaan (X3) naik satu satuan maka ROA akan turun sebesar 0,239. Demikian sebaliknya bila Ukuran Perusahaan 
(X3) turun satu satuan maka ROA akan naik sebesar 0,239 dengan asumsi variabel Perputaran Modal Kerja (X1) dan Likuiditas yang diukur dengan Current Rasio (X2) adalah konstan.

\section{Uji Hipotesis}

\section{a. Uji Parsial (Uji T)}

1. Perputaran Modal Kerja (X1) berpengaruh negatif dan (nyata) terhadap ROA (Y). Yang artinya hipotesis dapat diterima dengan tingkat signifikansi 0,000 >0,05.

2. Current Rasio (X2) tidak berpengaruh positif dan (tidak nyata) terhadap ROA (Y). Yang artinya hipotesis ditolak dengan tingkat signifikansi 0,765 >0,05.

3. Ukuran Perusahaan (X3) tidak berpengaruh negatif dan (tidak nyata) terhadap ROA (Y). Yang artinya hipotesis ditolak dengan tingkat signifikansi sebesar 0,499 > 0,05 .

\section{b. Uji Simultan (Uji F)}

\section{Tabel 8. Hasil Pengujian ANOVA (Uji F)}

ANOVA ${ }^{\mathrm{a}}$

\begin{tabular}{|ll|r|r|r|r|r|}
\hline Model & & Sum of Squares & \multicolumn{1}{|c|}{ Df } & Mean Square & \multicolumn{1}{l|}{ F } & Sig. \\
\hline 1 & Regression & 1851.970 & 3 & 617.323 & 7.933 & $.000^{\mathrm{b}}$ \\
& Residual & 2801.271 & 36 & 77.813 & & \\
& Total & 4653.241 & 39 & & & \\
\hline
\end{tabular}

a. Dependent Variable: $\mathrm{Y}=\mathrm{ROA}$

b. Predictors: (Constant), X3 = Size, X1 = Perputaran Modal Kerja, X2 = CR

Hasil analisis Uji F (uji kecocokan model) memperlihatkan bahwa nilai angka dari $F_{\text {hitung }}=7,933$ dengan signifikansi 0,000 $<0,05$. Yang berartinya Signifikan Positif, hasil ini memperlihatkan kesesuaian model bisa diterima. Dan kemudian bisa disimpulkan bahwa analisi regresi linier berganda yang dipakai pada penelitian ini telah sesuai sebagai alat analisis dengan tingkat signifikansi 0,000.

\section{c. Koefisien Determinasi $\left(\mathbf{R}^{2}\right)$}

\section{Tabel 9. Uji Koefisien Determinasi}

\begin{tabular}{|c|c|c|c|c|c|c|c|}
\hline \multicolumn{8}{|c|}{ Model Summary $^{b}$} \\
\hline \multirow[b]{2}{*}{ Model } & \multirow[b]{2}{*}{$\mathrm{R}$} & \multirow[b]{2}{*}{ R Square } & \multirow[b]{2}{*}{$\begin{array}{c}\text { Adjusted R } \\
\text { Square }\end{array}$} & \multirow{2}{*}{$\begin{array}{l}\text { Std. Error } \\
\text { of the } \\
\text { Estimate }\end{array}$} & \multicolumn{2}{|c|}{ Change Statistics } & \multirow[b]{2}{*}{ Durbin-Watson } \\
\hline & & & & & $\begin{array}{c}\text { R Square } \\
\text { Change }\end{array}$ & $\begin{array}{c}\text { Sig. F } \\
\text { Change }\end{array}$ & \\
\hline 1 & $.631^{\mathrm{a}}$ & .398 & 348 & 8.82117 & .398 & .000 & 2.457 \\
\hline
\end{tabular}

a. Predictors: (Constant), X3 = Size, X1 = Perputaran Modal Kerja, X2 = CR

b. Dependent Variable: $\mathrm{Y}=\mathrm{ROA}$

Berdasarkan hasil tabel 4 memperlihatkan hasil koefisien determinasi (R Square) sebesar 0,398 yang artinya variabel Perputaran Modal Kerja (X1), Likuiditas yang diukur dengan Current Rasio (X2) dan Ukuran Perusahaan (X3) mampu menjelaskan variabel Profitabilitas yang diukur dengan ROA (Y) sebesar 39,8\%. Sedangkan sisanya yaitu 60,2\% [100\% - 39,8\%] dijelaskan leh variabel lain selain Perputaran Modal Kerja, Likuiditas dan Ukuran Perusahaan. 


\section{Pembahasan}

\section{Pengaruh Perputaran Modal Kerja terhadap Profitabilitas}

Berdasarkan hasil uji hipotesis tabel 2 memperlihatkan bahwa perputaran modal kerja berpengaruh signifikan negatif terhadap profitabilitas yang diproksikan dengan ROA. Dapat dilihat melalui tingkat signifikansi yang lebih kecil dari 0,05 yaitu sebesar 0,000 dan mempunyai nilai koefisien regresi $-0,901$. Hal ini mengisyaratkan bahwa Hipotesis dapat diterima, namun dengan arah yang berlawanan. Artinya perputaran modal kerja yang mengalami peningkatan sebanyak 0,901 akan menurunkan tingkat profitabilitas perusahaan sebesar 0,901. Begitu pula sebaliknya.

Berdasarkan nilai perputaran modal kerja perusahaan Unilever Indonesia Tbk, yang memiliki nilai rata - rata paling rendah selama 4 tahun periode penelitian. Pada tahun 2016 nilai perputaran modal kerja sebesar -9,34. Pada tahun 2017 nilai perputaran modal kerja sebesar -8,89. Pada tahun 2018 nilai perputaran modal kerja sebesar -13,86. Dan pada tahun 2019 nilai perputaran modal kerja sebesar -9,46. Namun nyatanya perusahaan Unilever Indonesia Tbk dapat memberikan profitabilitas paling besar selama 4 tahun periode penelitian, yang dapat dilihat pada tabel 1. Perputaran yang tidak begitu tinggi cenderung lebih menghasilkan laba dari pada yang memiliki perputaran tinggi.Karena jika terjadi perputaran modal kerja yang berlebih menimbulkan penumpukan persediaan, dan perusahaan memiliki risiko yaitu kesulitan untuk menjual persediaan agar menjadi kas dan tentunya laba juga demikian. Disamping itu banyaknya persediaan yang dimiliki perusahaan akan menimbulkan biaya penyimpanan yang berlebih, dimana itu akan menurunkan tingkat profitabilitas.Hasil penelitian ini sesuai penelitian yang dilakukan Prakoso et al (2014) dan Reynata et al (2019) yang menyatakan bahwa perputaran modal kerja berpengaruh negatif signifikan terhadap profitabilitas. Sementara berbanding terbalik dengan penelitian Ambarwati et al (2015) yang menyatakan perputaran modal kerja berpengaruh possitif signifikan terhadap profitabilitas.

\section{Pengaruh Likuiditas terhadap Profitabilitas}

Berdasarkan uji hipotesis tabel 2 memperlihatkan bahwa likuiditas yang diukur dengan current rasio tidak berpengaruh signifikan terhadap profitabilitas yang diproksikan dengan ROA. Dapat dilihat melalui tingkat signifikansi yang lebih besar dari 0,05 yaitu sebesar 0,756 dan memiliki nilai koefisien regresi sebesar -0,003. Artinya likuiditas yang mengalami peningkatan sebesar 0,003 akan menurukan tingkat profitabilitas perusahaan sebesar 0,003. Begitu pula sebaliknya.

Berdasarkan data penelitian yaitu rata - rata nilai current rasio, diketahui pada tahun 2016 nilai CR sebesar 264,01\% dan memiliki nilai profitabilitas $14,95 \%$. Pada tahun 2017 nilai CR sebesar 264,63\% dan memiliki nilai profitabilitas 13,40\%. Pada tahun 2018 nilai CR sebesar 240,84\% dan memiliki nilai profitabilitas $14,18 \%$. Sementara pada tahun 2019 nilai CR sebesar 250,19\% dan memiliki nilai profitabilitas 13,19\%.Melalui data tersebut dapat diketahui jika hubungan likuiditas terhadap profitabilitas menunjukkan perubahan yang berlawanan arah, sesuai dengan hasil penelitian ini. Hal ini memberi arti bahwa dengan nilai likuiditas yang lebih rendah akan memberikan tingkat keefektifan dan 
keefisienan lebih baik untuk menghasilkan laba dari pada dengan nilai likuiditas yang tinggi. Semakin tinggi current rasio pada perusahaan akan menimbulkan penumpukan aktiva yang berlebih. Hal ini berpeluang besar dana akan menganggur dan tidak dimanfaatkan dengan baik oleh perusahaan. Yang akhirnya perusahaan akan kehilangan kesempatan untuk mendapat keuntungan. Sesuai dengan penelitian Yuliati (2013) dan Ambarwati et al (2015) yang menyatakan likuiditas tidak berpengaruh signifikan terhadap profitabilitas. Namun hasil penelitian Wahyuliza dan Dewita (2018), Alifianda dan Takarini (2020) memiliki hasil yang berbeda yang menyatakan likuiditas berpengaruh positif signifikan terhadap profitabilitas.

\section{Pengaruh Ukuran Perusahaan terhadap Profitabilitas}

Berdasarkan uji hipotesis tabel 2 memperlihatkan ukuran perusahaan tidak berpengaruh signifikan terhadap profitabilitas yang diproksikan dengan ROA. Dapat dilihat melalui tingkat signifikansi yang lebih besar dari 0,05 yaitu 0,499 dan memiliki nilai koefisien regresi sebesar -0,239. Artinya ukuran perusahaan yang mengalami peningkatan sebesar 0,239 akan menurunkan tingkaaat profitabilitas perusahaan sebesar 0,239. Begitu pula sebaliknya.

Berdasarkan data penelitian yaitu rata - rata nilai ukuran perusahaan, diketahui pada tahun 2016 nilai ukuran perusahaan sebesar 19,28 dan memiliki nilai profitabilitas 14,95\%. Pada tahun 2017 nilai ukuran perusahan sebesar 19,36 dan memiliki nilai profitabilitas 13,40\%. Pada tahun 2018 nilai ukuran perusahaan sebesar 18,75 dan memiliki nilai profitabilitas 14,18\%. Sementara tahun 2019 nilai ukuran perusahaan sebesar 18,85 dan memiliki nilai profitabilitas 13,19\%.Melalui data tersebut dapat diketahi bahwa jika hubungan ukuran perusahaan terhadap profitabilitas menunjukkan perubahan yang berlawanan arah, sesuai dengan hasil penelitian ini. Menurut Assani (2019) ukuran perusahaan tidak bisa dijadikan sebagai pengukuran untuk menilai kemampuan perusahaan dalam memperoleh laba. Karena perusahaan besar belum tentu dapat mengelola asetnya dengan maksimal. Perusahaan besar juga cenderung mudah untuk melakukan hutang, sehingga jika tidak mampu menentukan kebijakan hutang dengan baik maka aset perusahaan akan terus bertambah tanpa adanya pengelolaan yang efektif dan efisien. Perusahaan akan kehilangan kesempatan untuk memaksimalkan keuntungan. Sejalan dengan teori critical resouces yang dikemukakan oleh Rajan dan Zingales (2001) dalam Kusuma (2005) yang mengatakan skala perusahaan yang semakin besar akan meningkatkan profitabilitas, namun pada jumlah atau titik tertentu pada akhirnya ukuran perusahaan menyebabkan penurunan profitabilitas pada perusahaan. Sejalan dengan penelitian Rasyid et al (2014) menyatakan ukuran perusahaan tidak berpengaruh signifikan terhadap profitabilitas. Sementara berbeda dengan hasil penelitian Wahyu \& Ulfa (2020) yang menyatakan ukuran perusahaan berpengatuh positif signifikan terhadap profitabilitas. 


\section{KESIMPULAN DAN SARAN}

Dengan berlandaskan hasil analisis dan pembahasan dari riset ini, peneliti menarik kesimpulan bahwa (1)Modal Kerja, Likuiditas, dan Ukuran Perusahaanberpengaruh positif signifikan terhadap Profitabilitas secara simultan. Sementara secara parsial (2) Modal Kerja berpengaruh negatif signifikan terhadap Profitabilitas. (3) Likuiditas dan Ukuran Perusahaan tidak berpengaruh signifikan terhadap Profitabilitas.

Adapun saran yang ingin diberikan oleh penulis, yaitu sebagai berikut. Bagi perusahaan sebaiknya untuk lebih memperhatikan kebijakan pendanaan yang akan diambil untuk kegiatan operasional perusahaan, sehingga tingkat likuiditas perusahaan tidak terlalu tinggi namun cukup untuk beroperasi. Perusahaan juga bisa lebih memperhatikan permintaan konsumen yang ada dipasar, sehingga dapat memperkirakan jumlah produksi dan penjualan yang akan didapat oleh perusahaan. Dengan begitu persediaan perusahaan tidak menumpuk terlalu banyak, yang membuat aset perusahaan terlihat berlebih. Selain itu dengan banyaknya tingkat persediaan yang tidak segera dijadikan kas akan menimbulkan biaya penyimpanan yang berlebih yang akan menurunkan profitabilitas. Dan bagi peneliti selanjutnya yang akan mengambil topik penelitian sejenis, disarankan untuk berinovasi dan mengembangkan penelitian dengan variabel yang lebih beragam dan dengan sampel penelitian yang lebih banyak. Serta diharap mampu menghasilkan penelitian yang jauh lebih baik sehingga dapat memperkaya bukti - bukti empiris tentang faktor apa yang dapat mempengaruhi profitabilitas, guna menjadi referensi bagi peneliti selanjutnya. 


\section{DAFTAR PUSTAKA}

Alifianda, R., \& Takarini, N. (2020). Analisis Profitabilitas pada Perusahaan Foodand Beverages yang Terdaftar di Bursa Efek Indonesia Tahun 2015-2018. IDEI: Jurnal Ekonomi \& Bisnis, 1(2), 76-83.

Ambarwati, N. S., Yuniarta, G. A., AK, S., \& Sinarwati, N. K. (2015). Pngaruh modal kerja, likuiditas, aktivitas dan ukuran perusahaan terhadap profitabilitas pada perusahaan manufaktur yang terdaftar di bursa efek Indonesia. JIMAT (Jurnal Ilmiah Mahasiswa Akuntansi) Undiksha, 3(1).

Assani, A. N., \& Laily, N. (2019). Pengruh Modal Kerja, Likuiditas, Ukuran Perusahaan terhadap Profitabilitas Perusahaan Plastik dan Kemsan. Jurnal Ilmu dan Riset Manajemen (JIRM), 8(6).

Barus, A. C. (2013). Analisis Faktor-Faktor yang Mempengaruhi Profitabilitas pada Perusahaan Manufaktur yang Terdaftar di Bursa Efek Indonesia. Jurnal Wira Ekonomi Mikroskil: JWEM, 3(2), 111-121.

Felany, I. A., \& Worokinasih, S. (2018). Pengaruh Perputaran Modal Kerja, Leverage Dan Likuiditas Terhadap Profitabilitas (Studi Pada Perusahaan Sub Sektor Makanan Dan Minuman Yang Terdaftar Di Bursa Efek Indonesia Padatahun 2012-2016). Jurnal Administrasi Bisnis, 58(2), 119-128.

Hanafi, Mamduh M. 2016. Manajemen Keuangan. Edisi Kedua, Cetakan Pertama. Yogyakarta: BPFE-Yogyakarta.

Harmono. 2018. Manajemen Keuangan Berbasis Balance Scorecard. Cetakan Ketujuh. Jakarta: PT Bumi Aksara.

Jumingan. 2014. Analisis Laporan Keuangan. Cetakan Kelima. Jakarta: PT Bumi Aksara.

Kasmir. 2019. Analisis Laporan Keuangan. Cetakan Kedua belas. Depok: PT Raja Grafindo Persada.

Kusuma, H. (2005). Size Perusahaan dan Profitabilitas: Kajian Empiris terhadap Perusahaan Manufaktur yang Terdaftar di Bursa Efek Jakarta. Economic Journal of Emerging Markets, 10(1).

Kusumawati, R., \& Rosady, I. (2019). Pengaruh Struktur Modal dan Profitabilitas terhadap Nilai Perusahaan dengan Kpemilikan Manajerial sebagai Variabel Moderasi. Jurnal Manajemen Bisnis, 9(2), 147-160.

Liputan6.com. Deflasi Berturut - turut Jadi tanda Daya Beli Masyarakat Belum Pulih. 01 Okober 2020. https://www.liputan6.com/bisnis/read/4371337/deflasi-berturut-turutjadi-tanda-daya-beli-masyarakat-belum-pulih. [diakses pada 10 Oktober 2020]

Meidiyustiani, R. (2016). Pengaruh Modal Kerja, Ukuran Perusahaan, Pertumbuhan Penjualan dan Likuiditas terhadap Profitabilitas pada perusahaan manufaktur sektor industri barang konsumsi yang terdaftar di Bursa Efek Indonesia (BEI) periode tahun 2010-2014. Jurnal Akuntansi dan Keuangan, 5(2), 41-59.

Prakoso, B. (2014). Pengaruh perputaran modal kerja dan perputaran piutang terhadap profitabilitas (Studi pada perusahaan pembiayaan listing di BEI periode 20092013). Jurnal Administrasi Bisnis, 15(1).

Prihardi, Toto. 2013. Analisis Laporan Keuangan Lanjutan: Proyeksi \& Valuasi. Cetakan Pertama. Jakarta Pusat: Penerbit PPM. 
Rasyid, R., Rahmiati, R., \& Youlandari, T. P. (2014). Pengaruh Modal Kerja, Ukuran Perusahaan dan Leverage Operasi terhadap Profitabilitas pada Perusahaan Food and Beverage yang Terdaftar di Bursa Efek Indonesia. Jurnal Kajian Manajemen Bisnis, 3(2).

Ratnasari, L., \& Budiyanto, B. (2016). Pengaruh Leverage, likuiditas, Ukuran Perusahaan terhadap Profitabilitas pada perusahaan otomotif di BEI. Jurnal Ilmu dan Riset Manajemen (JIRM), 5(6).

Reynata, V., Irman, M., \& Hayati, R. (2019). Analisis Pengaruh Modal Kerja Terhadap Profitabilitas Pada Perusahaan Manufaktur Sub Sektor Logam dan Sejenisnya yang Terdaftar di Bursa Efek Indonesia Periode 2013-2017. Bilancia: Jurnal Ilmiah Akuntansi, 3(2), 232-243.

Riyanto, Bambang. 2010. Dasar - dasar Pembelanjaan Perusahaan. Edisi Keempat, Cetakan Kesepuluh. Yogyakarta: BPFE-Yogyakarta.

Ulfa, T. U., \& Widati, L. W. (2020). Perputaran Modal Kerja, Pertumbuhan Perusahaan, Ukuran Perusahaan dan Likuiditas Pengaruhnya Terhadap Profitabilitas (Studi kasus pada Bursa Efek Indonesia periode 2016-2018). Dinamika Akuntansi Keuangan dan Perbankan, 9(1), 59-68.

Wahyuliza, S., \& Dewita, N. (2018). pengaruh likuiditas, solvabilitas dan perputaran modal kerja terhadap profitabilitas pada perusahaan manufaktur yang terdaftar di Bursa Efek Indonesia. Jurnal Benefita, 3(2), 219-226.

Wibowo, A., \& Wartini, S. (2012). Efisiensi Modal Kerja, Likuiditas dan Leverage terhadap Profitabilitas pada Perusahaan Manufaktur di BEI. JDM (Jurnal Dinamika Manajemen), 3(1).

Yuliati, N. W. (2013). Pengaruh Kebijakan Modal Kerja Terhadap Profitabilitas Pada Perusahaan Hotel dan Restoran di Bursa Efek Indonesia. E-Jurnal Ekonomi dan Bisnis Universitas Udayana. 